\title{
A New Isolation and Evaluation Method for Marine-Derived Yeast spp. with Potential Applications in Industrial Biotechnology
}

\author{
Abdelrahman Saleh Zaky ${ }^{1,2,3}$, Darren Greetham ${ }^{1}$, Edward J. Louis ${ }^{4}$, Greg A. Tucker ${ }^{1}$, and Chenyu Du ${ }^{1,2 *}$ \\ ${ }^{1}$ Division of Food Sciences, School of Biosciences, University of Nottingham, Nottingham LE12 5RD, UK \\ ${ }^{2}$ School of Applied Sciences, University of Huddersfield, Huddersfield HD1 3DH, UK \\ ${ }^{3}$ Department of Microbiology, Faculty of Agriculture, Cairo University, Giza 12613, Egypt \\ ${ }^{4}$ Centre for Genetic Architecture of Complex Traits, Department of Genetics, University of Leicester, Leicester LE1 7RH, UK
}

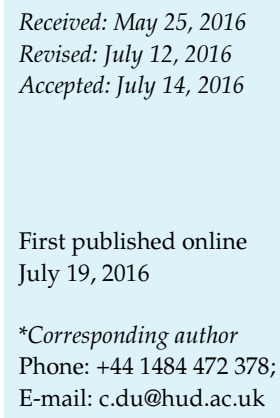

First published online July 19, 2016

*Corresponding author Phone: +44 1484472 378.

E-mail: c.du@hud.ac.uk

pISSN 1017-7825, eISSN 1738-8872

Copyright (C) 2016 by

The Korean Society for Microbiology and Biotechnology
Yeasts that are present in marine environments have evolved to survive hostile environments that are characterized by high exogenous salt content, high concentrations of inhibitory compounds, and low soluble carbon and nitrogen levels. Therefore, yeasts isolated from marine environments could have interesting characteristics for industrial applications. However, the application of marine yeast in research or industry is currently very limited owing to the lack of a suitable isolation method. Current methods for isolation suffer from fungal interference and/or low number of yeast isolates. In this paper, an efficient and nonlaborious isolation method has been developed and successfully isolated large numbers of yeasts without bacterial or fungal growth. The new method includes a three-cycle enrichment step followed by an isolation step and a confirmation step. Using this method, 116 marine yeast strains were isolated from 14 marine samples collected in the UK, Egypt, and the USA. These strains were further evaluated for the utilization of fermentable sugars (glucose, xylose, mannitol, and galactose) using a phenotypic microarray assay. Seventeen strains with higher sugar utilization capacity than the reference terrestrial yeast Saccharomyces cerevisiae NCYC 2592 were selected for identification by sequencing of the ITS and D1/D2 domains. These strains belonged to six species: S. cerevisiae, Candida tropicalis, Candida viswanathii, Wickerhamomyces anomalus, Candida glabrata, and Pichia kudriavzevii. The ability of these strains for improved sugar utilization using seawater-based media was confirmed and, therefore, they could potentially be utilized in fermentations using marine biomass in seawater media, particularly for the production of bioethanol and other biochemical products.

Keywords: Marine yeast, phenotypic microarray, identification, screening, fermentation, seawater

\section{Introduction}

Yeasts are eukaryotic unicellular microorganisms belonging to the fungal kingdom. Currently, there are around 1,500 described species of yeasts, which represent about $1 \%$ of the total fungal species existing in nature $[19,20]$. Yeasts, such as $S$. cerevisiae, have been successfully exploited in various industries such as ethanol production, bakery, wine making, and brewing. In order to satisfy the growing demand for a fermentation-based economy, researchers have been trying to isolate novel yeast strains with promising properties, such as high fermentation capability, high stress tolerance, and producing novel products [4, 47]. The vast majority of existing yeasts have been isolated from terrestrial resources such as sugar refineries, breweries, wineries, bakeries, and beet and cane molasses, as well as from various fruits and vegetables.

The marine environment, which accounts for $71 \%$ of the planet's surface area, has not been widely explored for yeast isolation. Recently, marine yeasts have been identified 
as a potential source for producing valuable compounds such as biofuels, amino acids, proteins, vitamins, polysaccharides, fatty acids, phospholipids, and enzymes $[6,35]$. These products have been shown to have potential for commercial exploitation. Research on marine yeasts has highlighted several promising features over terrestrial yeast strains, e.g. higher tolerance to extreme environments and higher productivity [28, 47]. Urano et al. [38] suggested that yeasts that inhabited a marine environment would have already developed a mechanism to tolerate high osmotic stress. However, utilization of marine yeasts for commercial purposes has not been widely established. This is often due to a lack of intensive research on marine yeast and the limited availability of marine yeast isolates [6, 46, 47].

Torula sp. and Mycoderma sp. were the first yeasts isolated from the marine environment in 1894 by Bernhard Fischer [23]. Since then, various other marine yeasts have been isolated from different marine sources, including seawater, sea sand [15, 39], seaweeds [36], fish, and different marine animals [3]. According to a recent report, the number of marine yeast species that have been classified and described has reached 213 species [13].

The development of an efficient and reliable isolation method for marine yeast will advance their employment of by introducing new species and strains with desired properties for research projects and industry. In general, the development of a marine yeast isolation method involves three aspects: (i) specify a sample collection technique, (ii) design a yeast isolation medium, and (iii) propose a strain isolation protocol. The main challenges in marine yeast isolation are the relatively low yeast population in the marine samples $[9,23]$ and the presence of molds [8]. To maximize the chance of obtaining a larger number of yeast strains from the marine samples, isolation was conducted within 2 days of sampling in most of the reported marine yeast isolation methods [1, 23]. The growth of bacteria contained in the marine samples can be inhibited by the addition of antibiotics [9]. However, growth of filamentous fungi could not be prevented, as there is no medium that is yeast specific and does not support the growth of filamentous fungi. Therefore, several strategies have been proposed in the isolation protocol development stage to minimize filamentous fungi growth, including reducing the incubation period $[7,15]$, reducing the amount of the sample to be used in the strain isolation [7], or reducing the incubation temperature [8, 26]. As a consequence of reducing the presence of filamentous fungi, yeast growth was also negatively affected. Therefore, the possibility of isolating a marine yeast was diminished.
The current methods for marine yeast isolation have several limitations, including (i) requirement of recent collected samples, (ii) utilizing growth media that encourage mold growth, and (iii) producing low numbers of yeast isolates. Therefore, the main objective of this study was to develop an efficient method for marine yeast isolation, including the design of new enrichment and isolation media and the construction of a new isolation protocol. In particular, the new method enables the usage of an aging marine sample for the potential isolation of marine yeasts. Furthermore, we designed a framework for screening large numbers of yeast isolates using a microarray technique, which was applied to 116 selected isolates. Seventeen isolates that showed high sugar utilization properties were identified by sequencing the ITS and D1/D2 domains and using the YT Micro plate technique (Biolog).

\section{Materials and Methods}

\section{Marine Samples}

Fourteen marine samples were obtained from different locations in the UK, Egypt, and the USA (Table 1). All samples were collected near the shore and were taken from a depth of a maximum of $1 \mathrm{~m}$ using $1 \mathrm{~L}$ sterilized plastic bottles with screw caps to prevent leaking and contamination. Samples were then transported immediately to the laboratory or sent by a courier to the laboratory. When samples were received at the laboratory, they were stored immediately in a fridge at $4^{\circ} \mathrm{C}$ until isolation was performed. The isolation was performed within 2 weeks of sampling.

\section{Seawater}

The seawater used in this paper for media preparation and dilutions was collected from the North Sea near Whitby, UK with salinity of about $33 \mathrm{~g} / \mathrm{l}$. The seawater was filtered using Whatman Glass microfiber filters (pore size, $1.2 \mu \mathrm{m}$ ) and autoclaved at $121^{\circ} \mathrm{C}$ for $15 \mathrm{~min}$, and then stored at $4^{\circ} \mathrm{C}$ until required.

\section{Microorganisms}

Besides isolated marine yeasts, a terrestrial strain $S$. cerevisiae (NCYC 2592; http://www.ncyc.co.uk) was used in this study as a reference strain. It was maintained on yeast peptone dextrose (YPD) agar slopes containing ( $\mathrm{w} / \mathrm{v}) 1 \%$ yeast extract, $2 \%$ peptone, $2 \%$ glucose, and $2 \%$ agar at $\mathrm{pH} 6 \pm 0.2$. Propagation was carried out aerobically using YPD broth medium (as above, no agar) in an orbital shaker $(150 \mathrm{rpm})$ at $30^{\circ} \mathrm{C}$.

Pure marine isolates were propagated using modified YM medium, containing $(\mathrm{w} / \mathrm{v}) 2 \%$ dextrose, $0.3 \%$ malt extract, $0.3 \%$ yeast extract, and $0.5 \%$ peptone dissolved in natural seawater (designated as SW-YM broth in this paper). The medium was adjusted to $\mathrm{pH} 5.0$ before autoclaving at $121^{\circ} \mathrm{C}$ for $15 \mathrm{~min}$. All marine yeast isolates were maintained on SW-YM agar slopes, 
Table 1. Distribution of new marine yeast isolates.

\begin{tabular}{|c|c|c|c|c|c|c|c|c|}
\hline & \multirow[b]{2}{*}{ Sample type } & \multirow[b]{2}{*}{ Locations } & \multicolumn{5}{|c|}{ Numbers of isolates using different substrates } & \multirow[b]{2}{*}{ Total Isolates } \\
\hline & & & Glucose & Xylose & Galactose & Starch & Cellulose & \\
\hline A & Seawater & Alexandria, Egypt & 4 & 3 & 3 & $\mathrm{~N} / \mathrm{A}$ & $\mathrm{N} / \mathrm{A}$ & 10 \\
\hline B & Seawater & Swiss, Egypt & 3 & 2 & 2 & $\mathrm{~N} / \mathrm{A}$ & $\mathrm{N} / \mathrm{A}$ & 7 \\
\hline $\mathrm{C}$ & Seawater & Ras Sedr, Egypt & 7 & 0 & 2 & 3 & $\mathrm{~N} / \mathrm{A}$ & 12 \\
\hline $\mathrm{D}$ & Seawater & Ismailia, Egypt & 4 & 2 & 2 & 2 & $\mathrm{~N} / \mathrm{A}$ & 10 \\
\hline $\mathrm{E}$ & Seawater & Wales 1 , UK & 1 & 0 & 2 & $\mathrm{~N} / \mathrm{A}$ & $\mathrm{N} / \mathrm{A}$ & 3 \\
\hline $\mathrm{F}$ & Seawater & Wales 2, UK & 3 & 2 & 2 & $\mathrm{~N} / \mathrm{A}$ & 3 & 10 \\
\hline G & Seawater & Plymouth1, UK & 4 & 3 & 2 & 3 & $\mathrm{~N} / \mathrm{A}$ & 12 \\
\hline $\mathrm{H}$ & Seawater & Plymouth2, UK & 4 & 2 & 2 & $\mathrm{~N} / \mathrm{A}$ & 1 & 9 \\
\hline I & Sea sand & Alexandria, Egypt & 3 & 0 & 3 & $\mathrm{~N} / \mathrm{A}$ & $\mathrm{N} / \mathrm{A}$ & 6 \\
\hline $\mathrm{J}$ & Seaweed & Plymouth3, UK & 3 & 1 & 3 & $\mathrm{~N} / \mathrm{A}$ & 6 & 13 \\
\hline K & Rotten seaweed & Plymouth4, UK & 2 & 1 & 2 & $\mathrm{~N} / \mathrm{A}$ & $\mathrm{N} / \mathrm{A}$ & 5 \\
\hline $\mathrm{L}$ & Seawater & Whitby, UK & 3 & 0 & 0 & $\mathrm{~N} / \mathrm{A}$ & $\mathrm{N} / \mathrm{A}$ & 3 \\
\hline M & Seawater & New York, USA & 2 & 3 & 2 & 1 & $\mathrm{~N} / \mathrm{A}$ & 8 \\
\hline \multirow[t]{2}{*}{$\mathrm{N}$} & Seawater & San Diego, USA & 3 & 2 & 2 & 1 & $\mathrm{~N} / \mathrm{A}$ & 8 \\
\hline & Total & & 46 & 21 & 29 & 10 & 10 & 116 \\
\hline
\end{tabular}

containing the above-mentioned SW-YM broth with the addition of $2 \%(\mathrm{w} / \mathrm{v})$ agar. Glycerol stock of each marine isolate was prepared using 1:1 glycerol and yeast broth that was cultured in SW-YM broth for $48 \mathrm{~h}$. The glycerol stocks were stored at $-80^{\circ} \mathrm{C}$.

\section{List of Microbiological Media Used in This Study}

SW-YM broth (w/v): $2 \%$ dextrose, $0.3 \%$ malt extract, $0.3 \%$ yeast extract, and $0.5 \%$ peptone.

SW-YM agar (w/v): $2 \%$ dextrose, $0.3 \%$ malt extract, $0.3 \%$ yeast extract, $0.5 \%$ peptone, and $2 \%$ agar.

YM medium (w/v): $1 \%$ glucose, $0.3 \%$ yeast extract, $0.3 \%$ malt extract, $0.5 \%$ peptone, and $2 \%$ agar [43].

Sabouraud's Dextrose Agar (SDA) (Oxoid, UK): $65 \mathrm{~g}$ of commercial medium was dissolved in $1 \mathrm{~L}$ of water to reach the following concentrations: $4 \%$ glucose, $1 \%$ mycological peptone, and $1.5 \%$ agar $(\mathrm{w} / \mathrm{v})$, with a final $\mathrm{pH}$ of 5.6 .

Zaky's enrichment medium (w/v): $3 \%$ glucose, $3 \%$ xylose, $0.3 \%$ malt extract, $0.3 \%$ yeast extract, $0.5 \%$ peptone, $0.1 \%\left(\mathrm{NH}_{4}\right)_{2} \mathrm{SO}_{4}$ and $0.025 \% \mathrm{KH}_{2} \mathrm{PO}_{4}$

Zaky's isolation broth medium (w/v): $6 \%$ glucose or alternative carbohydrate source (i.e., xylose, galactose, starch, or cellulose), $0.3 \%$ yeast extract, $0.5 \%$ peptone, $0.1 \%\left(\mathrm{NH}_{4}\right)_{2} \mathrm{SO}_{4}$, and $0.025 \%$ $\mathrm{KH}_{2} \mathrm{PO}_{4}$

Zaky's isolation agar medium (w/v): $6 \%$ glucose or alternative carbohydrate source (i.e., xylose, galactose, starch, or cellulose), $0.3 \%$ yeast extract, $0.5 \%$ peptone, $0.1 \%\left(\mathrm{NH}_{4}\right)_{2} \mathrm{SO}_{4}, 0.025 \% \mathrm{KH}_{2} \mathrm{PO}_{4}$ and $2 \%$ agar.

All components were dissolved in seawater or deionized water and adjusted to the required $\mathrm{pH}$ using either $\mathrm{NaOH}$ or $\mathrm{HCl}(1 \mathrm{~N})$, and then autoclaved at $121^{\circ} \mathrm{C}$ for $15 \mathrm{~min}$.

\section{Marine Yeast Isolation Methods}

Three marine yeast isolation methods were used in this study.

Isolation method 1: Kutty method [22]. Isolation of marine yeasts was carried out by filtration and pour plate using the method described by Kutty [22] with some modifications. First, $30 \mathrm{ml}$ of seawater was filtered through nitrocellulose filters (pore size $0.45 \mu \mathrm{m}$ ) using an autoclaved filter apparatus (Fisher). For solid marine samples (sea sand or seaweed), $10 \mathrm{~g}$ of each sample was suspended and vortexed in $30 \mathrm{ml}$ of sterilized seawater. Then, the seawater containing the solid marine sample was filtered through nitrocellulose filters (pore size $0.45 \mu \mathrm{m}$ ) using an autoclaved filter apparatus (Fisher). The filters were then placed face up on an empty petri dish followed by the addition of YM medium (using seawater and supplemented with chloramphenicol (200 mg/l) after autoclaving) and incubated at room temperature $23 \pm 1^{\circ} \mathrm{C}$ for 14 days.

Isolation method 2: Dinesh method [7]. Isolation of marine yeast was carried out by serial dilution and pour plate using the method described by Dinesh et al. [7] with some modifications. First, $1 \mathrm{ml}$ of seawater was serially diluted with sterilized seawater to reach a dilution factor range of $10^{-1}$ to $10^{-6}$. Then, $1 \mathrm{ml}$ of the original sample or the diluted sample was transferred to an empty petri dish, followed by pouring of melted and cooled SDA, prepared using $50 \%$ seawater. For solid samples, $1 \mathrm{~g}$ of the sample was suspended and vortexed in $10 \mathrm{ml}$ of sterilized seawater. Then, it was serially diluted with sterilized seawater to reach a dilution factor range from $10^{-1}$ to $10^{-6}$. After that, $1 \mathrm{ml}$ from each dilution was transferred into an empty petri dish, followed by pouring of melted and cooled SDA prepared using 50\% seawater, and then 


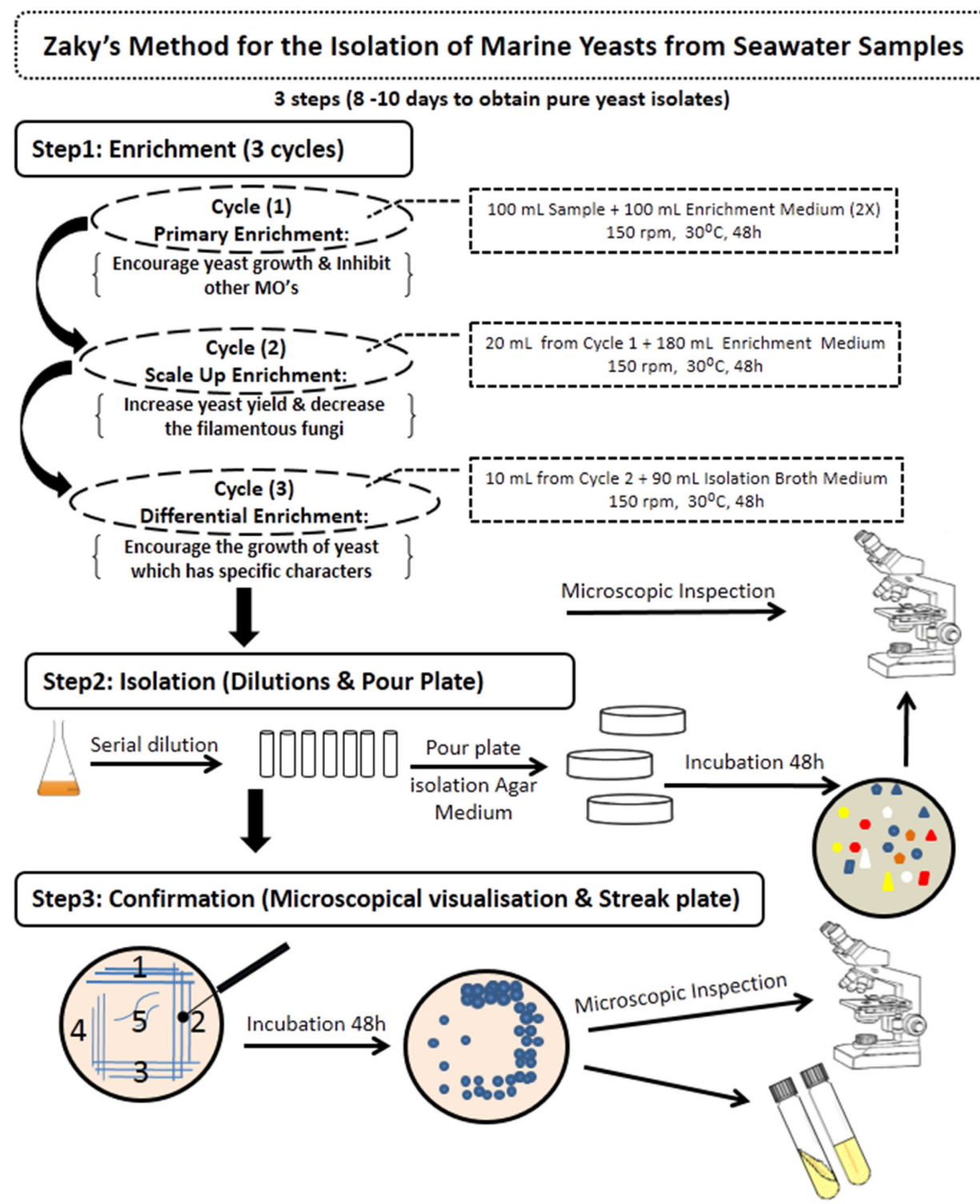

Fig. 1. Schematic diagram of the new marine yeast isolation method proposed in this study.

incubation at $35^{\circ} \mathrm{C}$ for $48 \mathrm{~h}$.

Isolation method 3: the new method developed in this study. The new method developed in this study involves three steps (Fig. 1). The first step was three cycles of enrichment, including a Primary Enrichment cycle, a Scale-Up Enrichment cycle, and a Differential Enrichment cycle. In the second step, the isolation of yeasts from the final enriched culture was carried out using the pour-plate technique. The final step was conducted using the streak-plate technique, followed by microscopic examination of selected colonies to confirm the purity of the new isolates.

In the Primary Enrichment cycle, $100 \mathrm{ml}$ of seawater samples was transferred into a $500 \mathrm{ml}$ conical flask containing $100 \mathrm{ml}$ of $2 \times$ Zaky's enrichment medium. For solid samples, $20 \mathrm{~g}$ of the sample was transferred into a $500 \mathrm{ml}$ conical flask containing $100 \mathrm{ml}$ of
Zaky's enrichment medium. Then, the flasks were incubated in a shaking incubator $(180 \mathrm{rpm})$ at $30^{\circ} \mathrm{C}$ for $48 \mathrm{~h}$.

In the Scale-Up Enrichment cycle, $20 \mathrm{ml}$ of culture from the Primary Enrichment cycle was transferred into a $500 \mathrm{ml}$ conical flask containing $180 \mathrm{ml}$ of Zaky's enrichment medium. Then, the flasks were incubated in a shaking incubator $(180 \mathrm{rpm})$ at $30^{\circ} \mathrm{C}$ for $48 \mathrm{~h}$.

In the Differential Enrichment cycle, $10 \mathrm{ml}$ of culture from the Scale-up Enrichment cycle was transferred into a $250 \mathrm{ml}$ conical flask contained $90 \mathrm{ml}$ of Zaky's isolation broth medium. Then, the flasks were incubated in a shaking incubator $(180 \mathrm{rpm})$ at $30^{\circ} \mathrm{C}$ for $48 \mathrm{~h}$.

All media used in this step were prepared using seawater and adjusted to $\mathrm{pH} 5.0$ using $\mathrm{HCl}(1 \mathrm{~N})$. A mixture of antibiotics 
(penicillin-G $500 \mathrm{mg} / \mathrm{l}$ and streptomycin sulfate $500 \mathrm{mg} / \mathrm{l}$ ) was added to all enrichment media after autoclaving. Microscopic inspection was carried out after each enrichment cycle to monitor the type of growth after the period of cultivation.

In the second step (isolation step), a 10-fold serial dilution was carried out from the Differential Enrichment cycle, and $1 \mathrm{ml}$ of diluted broth (with a dilution factor of $10^{-4}$ to $10^{-7}$ ) was transferred into a petri dish and then poured with $10 \mathrm{ml}$ of Zaky's isolation agar medium. The plates were then incubated for $48 \mathrm{~h}$ at $30^{\circ} \mathrm{C}$.

In the third step (confirmation step), selected single colonies from the isolation step were streaked on fresh SW-YM agar plates and incubated for $48 \mathrm{~h}$ at $30^{\circ} \mathrm{C}$, followed by microscopic examination of smear slides stained with methylene blue.

\section{Screening and Metabolism Evaluation Using Phenotypic Microarray (PM) Assay}

PM assays were carried out using sterilized empty Biolog 96well plates based on the method developed by Greetham et al. [11] with minor modifications. Each well in the plate was supplied with a mixture of growth medium $(30 \mu \mathrm{l})$ and buffered cell suspension $(90 \mu \mathrm{l})$. Stock solutions of $(40 \%(\mathrm{w} / \mathrm{v}))$ of each sugar (glucose, mannitol, xylose, and galactose) and $(28.7 \%(\mathrm{w} / \mathrm{v}))$ of yeast nitrogen base (YNB) were prepared individually in seawater and then filter sterilized. Sugars were prepared from the stock solutions to give a $6 \%(\mathrm{w} / \mathrm{v})$ final concentration per well and $0.67 \%(\mathrm{w} / \mathrm{v})$ of YNB in the well's final volume $(120 \mu \mathrm{l})$. Hence, $18 \mu \mathrm{l}$ of stock solution's sugar, $2.8 \mu \mathrm{l}$ of YNB stock solution, $9 \mu \mathrm{l}$ of seawater, and $0.2 \mu \mathrm{l}$ of dye D (Biolog, Hayward, CA, USA) were aliquoted to individual wells in the Biolog 96-well plate. Marine isolates and the reference strain were prepared for inoculation into the PM assay plates as follows: A fresh culture (48 h) on SWYM agar slope was prepared from stock cultures stored at $4^{\circ} \mathrm{C}$. A small amount of yeast growth was transferred into test tubes $(20 \times$ $100 \mathrm{~mm}$ ) that contained $10 \mathrm{ml}$ of sterile seawater and transmittance was adjusted to $62 \%\left(\sim 5 \times 10^{6}\right.$ cells $\left./ \mathrm{ml}\right)$ (turbidimeter; Biolog). Then, $1 \mathrm{ml}$ of the cell suspension was added to $5 \mathrm{ml}$ of IFY buffer (Biolog) to obtain the cell suspension for the inoculum. Next, $90 \mu \mathrm{l}$ of the above cell suspension was inoculated into each well of the Biolog plate. Semi-anaerobic conditions were created by placing the plates inside PM gas bags (Biolog) and vacuum sealing them using DMC 260PD Vacuum Packaging Machine. Inoculated plates were then incubated at $30^{\circ} \mathrm{C}$ in the Omnilog plate reader (Biolog) and the reading was recorded every $15 \mathrm{~min}$ for $24 \mathrm{~h}$. By the end of the run, the signal data were compiled and exported from the Biolog software using Microsoft Excel. Only the isolate that had a final Biolog reading (redox signal intensity) of 20 or over was counted. All experiments were performed in triplicates, and the mean signal values are presented.

\section{PCR-Based Method (D1/D2 and ITS Primers) for Yeast Identification}

Identification of selected marine isolates was carried out based on the sequence of the D1/D2 region of the large 26S rDNA subunit using primers NL-1 (5'-GCATATCAATAAGCGGAG GAAAAG-3') and NL-4 (5'-GGTCCGTGTTTCAAGACGG-3'). Identification was also performed using the internal transcribed spacer (ITS) region (5.8S rRNA) using primers ITS1 (5'-TCC GTAGGTGAACCTGCGG-3') and ITS4 (5'-TCCTCCGCTTATTGA TATG-3') as described by White et al. [41] and Mitchell et al. [25].

For the PCR master mix for PCR amplification, each reaction contained $8 \mu \mathrm{l}$ of $10 \times$ PCR buffer, 1 unit of Taq DNA polymerase, $25 \mathrm{pmol}$ of each forward and reverse primers, $100 \mu \mathrm{M}$ of each deoxynucleoside triphosphate, and enough distilled water up to a total reaction volume of $50 \mu \mathrm{l}$. A small amount of yeast growth from a culture (24-48 h) was picked using a micropipette tip and suspended in $50 \mu \mathrm{l}$ of deionized water and then incubated for $10 \mathrm{~min}$ at $95^{\circ} \mathrm{C}$. Then, $4 \mu \mathrm{l}$ of the preheated yeast suspension was transferred into the PCR tubes as a DNA template. The tubes were then placed in a thermocycler (TECHNE TC-5, UK), using the following settings: initial denaturation at $98^{\circ} \mathrm{C}$ for $30 \mathrm{sec}$, followed by 35 cycles of $98^{\circ} \mathrm{C}$ for $15 \mathrm{sec}, 52^{\circ} \mathrm{C}$ (for D1/D2 primers) or $54^{\circ} \mathrm{C}$ (for ITS primers) for $45 \mathrm{sec}$, and $72^{\circ} \mathrm{C}$ for $90 \mathrm{sec}$, with a final extension step of $72^{\circ} \mathrm{C}$ for $5 \mathrm{~min}$. The PCR products were detected by electrophoresis separation using $1 \%$ agarose gel containing $4 \mu \mathrm{l}$ of ethidium bromide in TBE buffer (0.09 M Tris, $0.09 \mathrm{M}$ boric acid, and $2 \mathrm{mM}$ EDTA, pH 8.3). A PCR cleaning kit (Sigma-Aldrich, UK) was used for purification before sequencing. The sequences obtained were aligned using BLAST analysis (http://www.ncbi. nlm.nih.gov/BLAST) for comparison with currently available sequences.

The ITS and D1/D2 phylogenetic comparisons were done with the core sequences shared by all PCR clones; that is, any long sequences were trimmed so that all bases were included in the multiple sequence alignments. Sequences that were too short were not included. The alignments were made with DNAStar Megalign, and the cladograms of the phylogenetic relationships were constructed with ClustalW embedded within Megalign. Bootstrap analysis was done using 1,000 generated trees.

\section{YT MicroPlate (Biolog System) for Yeast Identification}

Biolog YT MicroPlate (Biolog) was used to identify 17 of the marine isolates and the reference strain. YT MicroPlate contained pre-prepared substrates for 94 different tests in a ready-to-use 96 BioLog microplate with two reference wells. Fresh cultures (48 h) were prepared on malt extract agar slopes using the working culture stocks that were stored at $4^{\circ} \mathrm{C}$. For each strain, a small amount of yeast broth was aseptically transferred into a test tube $(20 \times 100 \mathrm{~mm})$, which contained sterile deionized water. Then, the test tube was placed on a Biolog turbidimeter to reach a transmittance of $48 \%$. Using a multichannel micropipette, one YT MicroPlate was used for each strain by loading $100 \mu \mathrm{l}$ of the cell suspension into each well. Plates were incubated at $26^{\circ} \mathrm{C}$ and the reads were taken after 24,48 , and $72 \mathrm{~h}$ at a wavelength of $450 \mathrm{~nm}$ for oxidation tests (the upper 3 rows in the plate) and a wavelength of $590 \mathrm{~nm}$ for assimilation tests (the other 5 rows in the plate) using a TECAN (Infinite 200 PRO) plate reader. Reads 
were generated and manually converted to values (positive, negative, and weak). All reads below 0.1 were considered negative, reads between 0.1 and 0.3 were considered weak reaction, and any reads above 0.3 were considered positive. The results were sent to Technopath for identification using the MicroLog manual microbial ID system.

\section{Results}

Development of a Methodology for the Isolation of Yeasts from a Marine Environment

In this study, two methods that were developed for isolation of marine yeast from newly collected samples, the Kutty method [22] and Dinesh method [7], were used for the isolation of yeasts from the 14 marine samples we collected (Table 1). As our samples were approximately 2 weeks old, no yeast colonies were obtained using either method. Instead, mold colonies were obtained from 10 of the 14 samples using Kutty's method (data not shown).

Based on these results, a new marine yeast isolation method was required to isolate yeast from marine environments. The new methodology involved three steps: enrichment, isolation, and confirmation. By the end of the enrichment step, yeast cell numbers reached $10^{5}-10^{8}$ cells $/ \mathrm{ml}$, while mold and bacterial cell growth was inhibited. An inspection after each enrichment cycle revealed that the number of fungi-like cells decreased between cycles (Fig. 2A).

Three cell culture cycles ( 2 days each) were designed to reduce filamentous fungal strains, as yeast cells are expected to grow faster than fungal strains in a liquid medium with high sugar concentration. For the third enrichment cycle, different carbon sources were used to screen for yeast strains with potentially desirable sugar utilization phenotypes.

Following three cycles of enrichment, large numbers of yeast colonies were obtained with no obvious bacterial or fungal colonies observed on the agar plates of the isolation step. The morphologies of each colony, such as color (white, cream, yellowish, red), shape (circular, oval, irregular, spindle, star, triangle), size (small, medium, large), surface (smooth, fluffy, rough, dry), and elevation (flat, raised, convex) were recorded. Colonies that were present on the same plate and had the same appearance were considered to be the same strain.

Table 2 shows the yeast viable count (YVC) of the isolates from various samples. When glucose was used as the carbon source in the third cycle of enrichment and isolation

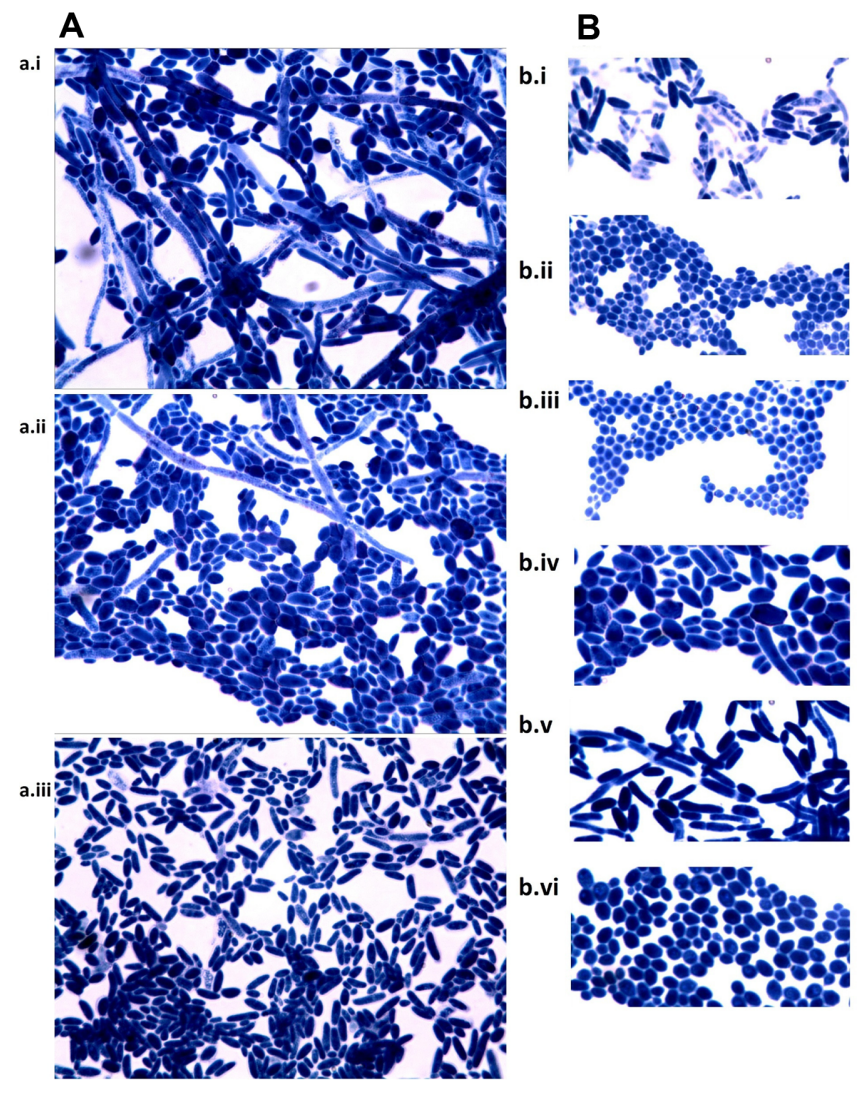

Fig. 2. Images of microorganisms obtained at different stages of isolation.

(A) Microscopic images $(1,000 \times)$ of the cultures after each enrichment cycle. a. i: primary enrichment cycle; a. ii: scale-up enrichment cycle; a. iii: differential enrichment cycle. The strains were stained with methylene blue. (B) Microscopic images $(1,250 \times)$ after the confirmation step for six newly isolated marine yeasts that represent different species: b.i, P. kudriavzevii; b.ii, C. glabrata; b.iii, W. anomalus; b.iv, C. viswanathii; b.v, C. tropicalis; and b.vi, S. cerevisiae. Polymorphic yeast cells appear in b.iv, C. viswanathii.

media, the YVC ranged from 24.7 to 220 million CFU / ml. A similar YVC range was obtained when galactose was used as the carbon source in the final cycle of enrichment and isolation media (Table 2). In comparison with glucose and galactose, using xylose as the carbon source resulted in a significant reduction of YVC in almost all samples, indicating glucose and galactose were relatively preferred substrates for marine yeasts. Starch was also used as a sole carbon source in the last step of enrichment. Isolates were obtained in five samples, and the YVC ranged from 0.25 to 2.0 million $\mathrm{CFU} / \mathrm{ml}$. When cellulose was used, isolates were detected in three samples (F, H, and J), and YVCs were 2.0, 0.55 , and 0.5 million CFU $/ \mathrm{ml}$, respectively (Table 2). 
Table 2. Yeast viable count of the isolates for 14 marine samples using Zaky's isolation method.

\begin{tabular}{|c|c|c|c|c|c|}
\hline Isolation media & Glucose & Xylose & Galactose & Starch & Cellulose \\
\hline Samples & \multicolumn{5}{|c|}{ CFU/ml (million ${ }^{\mathrm{a}}$ ) } \\
\hline A & $206.67 \pm 20.82$ & $32.67 \pm 4.04$ & $230.00 \pm 20.00$ & $\mathrm{~N} / \mathrm{A}$ & $\mathrm{N} / \mathrm{A}$ \\
\hline B & $220.00 \pm 20.00$ & $5.53 \pm 0.45$ & $45.33 \pm 4.51$ & $\mathrm{~N} / \mathrm{A}$ & $\mathrm{N} / \mathrm{A}$ \\
\hline C & $49.00 \pm 3.61$ & $\mathrm{~N} / \mathrm{A}$ & $25.67 \pm 6.03$ & $0.75 \pm 0.05$ & $\mathrm{~N} / \mathrm{A}$ \\
\hline $\mathrm{D}$ & $24.67 \pm 5.03$ & $14.33 \pm 4.04$ & $86.33 \pm 4.04$ & $1.60 \pm 0.28$ & $\mathrm{~N} / \mathrm{A}$ \\
\hline $\mathrm{E}$ & $42.67 \pm 5.03$ & $1.77 \pm 0.64$ & $17.33 \pm 5.03$ & $\mathrm{~N} / \mathrm{A}$ & $\mathrm{N} / \mathrm{A}$ \\
\hline $\mathrm{F}$ & $129.00 \pm 5.57$ & $7.97 \pm 2.28$ & $83.67 \pm 7.77$ & $\mathrm{~N} / \mathrm{A}$ & $2.00 \pm 0.46$ \\
\hline G & $24.33 \pm 4.51$ & $12.33 \pm 2.52$ & $68.33 \pm 3.51$ & $1.80 \pm 0.15$ & $\mathrm{~N} / \mathrm{A}$ \\
\hline $\mathrm{H}$ & $91.67 \pm 3.51$ & $34.67 \pm 5.03$ & $20.67 \pm 3.06$ & $\mathrm{~N} / \mathrm{A}$ & $0.50 \pm 0.13$ \\
\hline I & $73.33 \pm 6.66$ & $25.33 \pm 4.51$ & $38.67 \pm 9.16$ & $\mathrm{~N} / \mathrm{A}$ & $\mathrm{N} / \mathrm{A}$ \\
\hline $\mathrm{J}$ & $38.33 \pm 5.69$ & $39.33 \pm 5.51$ & $61.67 \pm 7.77$ & $\mathrm{~N} / \mathrm{A}$ & $0.55 \pm 0.05$ \\
\hline K & $27.00 \pm 4.58$ & $14.67 \pm 3.51$ & $\mathrm{~N} / \mathrm{A}$ & $\mathrm{N} / \mathrm{A}$ & $\mathrm{N} / \mathrm{A}$ \\
\hline $\mathrm{L}$ & $122.67 \pm 7.37$ & $30.33 \pm 6.11$ & $84.67 \pm 6.11$ & $\mathrm{~N} / \mathrm{A}$ & $\mathrm{N} / \mathrm{A}$ \\
\hline M & $106.33 \pm 12.10$ & $4.37 \pm 0.78$ & $33.67 \pm 6.51$ & $0.75 \pm 0.10$ & $\mathrm{~N} / \mathrm{A}$ \\
\hline $\mathrm{N}$ & $169.33 \pm 14.36$ & $31.00 \pm 15.10$ & $33.33 \pm 7.64$ & $0.25 \pm 0.13$ & $\mathrm{~N} / \mathrm{A}$ \\
\hline
\end{tabular}

${ }^{a}$ Average of 3 replicates; \pm standard deviation.

In the third enrichment step, the purity of the 116 selected colonies was confirmed by streaking them on a second agar plate. Those colonies were selected to represent different sample sources, different isolation media, and different colony morphology. Microscopic images showed that some of the isolates were polymorphologically yeast-like cells (Fig. 2B).

\section{Determination of Yeast Metabolic Output on Monomeric} Fermentable Sugars Using a Phenotypic Microarray Assay

The ability of the 116 marine yeast isolates to utilize glucose, mannitol, xylose, and galactose in seawater-based media was assessed using a PM assay. The terrestrial yeast S. cerevisiae NCYC 2592 was included in this study as a reference strain. S. cerevisiae NCYC2592 had been well defined previously for sugar utilization and tolerance to the presence of inhibitory compounds [29, 45].

Results revealed that 96 out of the 116 marine isolates were able to utilize glucose in a seawater-based medium, and 11 of the marine isolates utilized a higher amount of glucose than the reference strain. Thirty-eight out of the 116 marine isolates were able to utilize mannitol, with 26 of them showing better utilization than the reference strain. Thirty-nine out of the 116 marine isolates were able to utilize galactose with three of them showing a better utilization of galactose than the reference strain. Twenty marine strains were able to utilize xylose, whereas the reference strain was not able to (Fig. 3).
Genetic Identification of Marine Yeast Isolates and Phenotypic Characterization

Based on the results of the PM assay, 17 strains (Table 3) with interesting sugar utilization abilities were selected for identification using D1/D2 and ITS sequencing. The length of PCR sequences of all isolates ranged between 553 and 677 nucleotides with D1/D2 primers, and 418 and 839 nucleotides with ITS primers, which was sufficient for identification. All sequences obtained were blasted against sequences in GenBank, EMBL, DDBJ, and PDB (http:// blast.ncbi.nlm.nih.gov/). Out of the 17 isolates, nine isolates belonged to the genus Candida as follows: C. tropicalis (4 isolates), C. viswanathii (4 isolates), and C. glabrata (1 isolate). The rest of the isolates were S.cerevisiae (4 isolates), W. anomalus (3 isolates), and P. kudriavzevii (1 isolate) (Table 3). The ID\% for all identified isolates was at least $99 \%$.

In Fig. 4, the phylogram of the D1/D2 sequences (Fig. 4A) and the ITS sequences (Fig. 4B) based on a ClustalW alignment are shown. Bootstrap support is shown as a percent age out of 1,000 trees. The phylogenetic relationships of both sequence sets are essentially the same, and are consistent with the known phylogenies of the species based on larger sequence comparisons.

When Biolog YT MicroPlate and the Biolog database were used for the identification of the isolates, the results differed from those obtained using the PCR-based method (Table 3). No identification was obtained for five isolates: S10, S62, S69, S83, and S84. Out of the 12 identified isolates, 


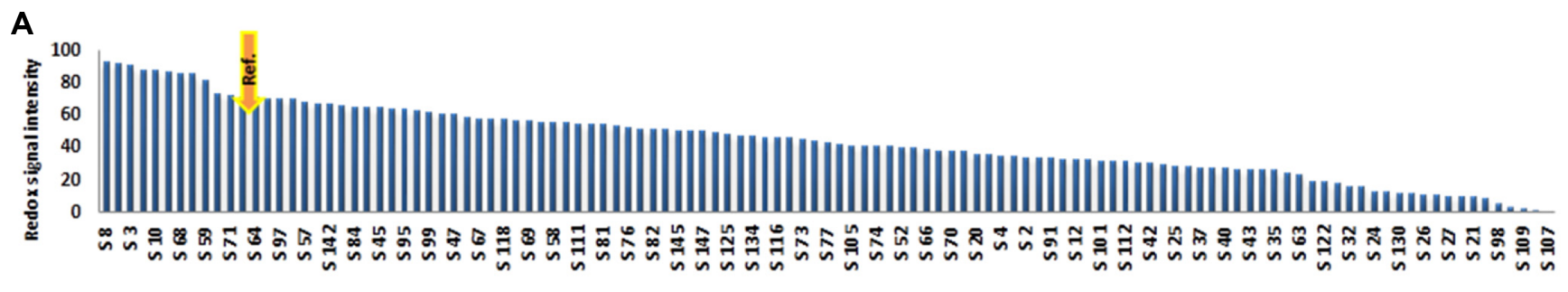

Marine Isolates

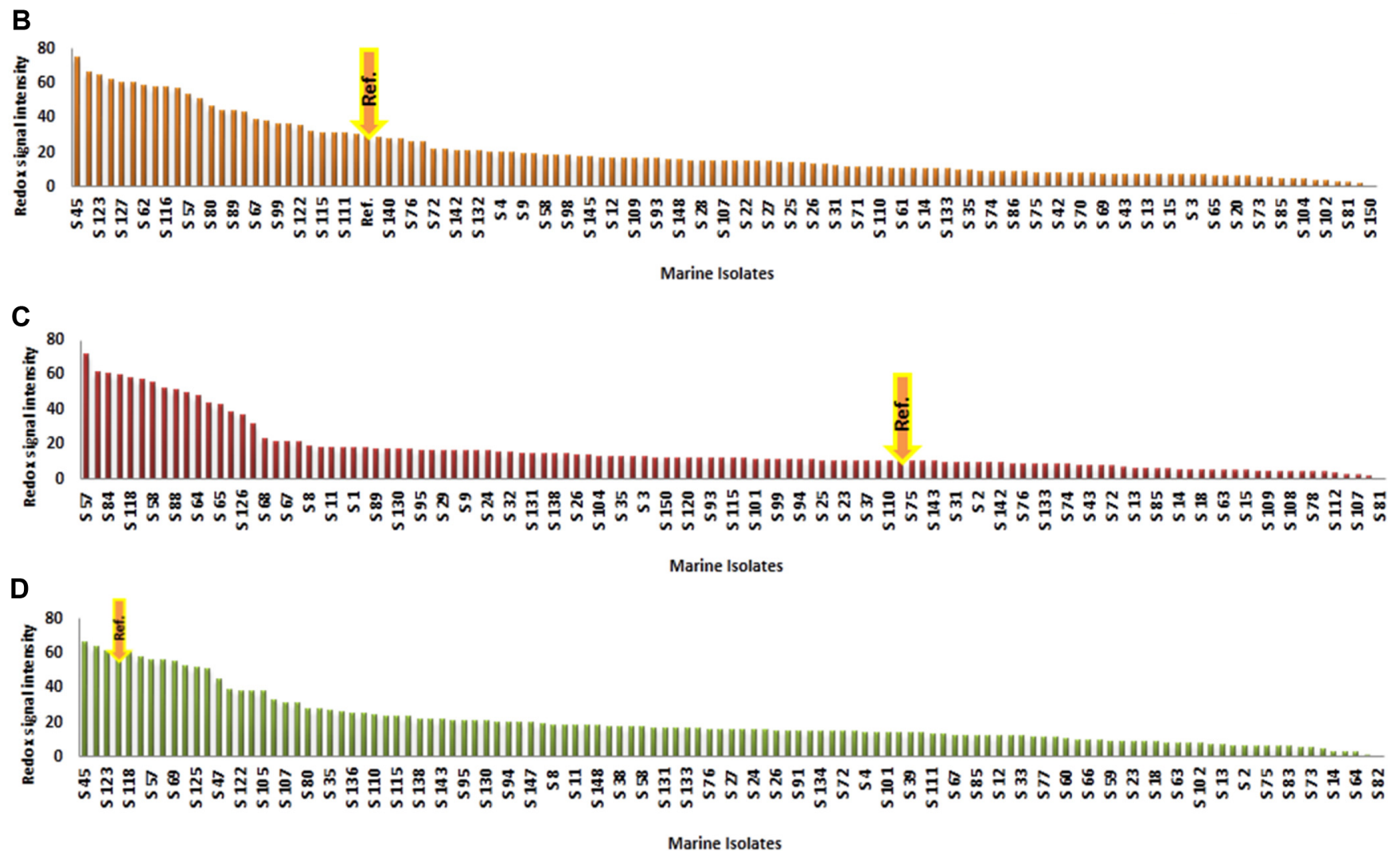

Fig. 3. Metabolic output of 116 marine yeast isolates and the reference strain S. cerevisiae NCYC2592 (Ref.) on 4 monomeric fermentable sugars using a phenotypic microarray assay.

(A) Glucose 6\% in Seawater; (B) Mannitol 6\% in Seawater; (C) Xylose 6\% in Seawater; (D) Galactose 6\% in Seawater.

six isolates matched the genetic identification at the genus level, but none matched at the species level. The identified isolates of C. viswanathii strains S1, S7, and S8 were identified as Hyphopichia burtonii, Rhodotorula acheniorum, and Candida parapsilosis, respectively, according to Biolog YT MicroPlate. C. tropicalis strains S45, S57, and S68 were identified as Candida albicans. S. cerevisiae isolates S117 and S118 were identified as Saccharomyces boulardii, and S71 was identified as Kluyveromyces marxianus. W. anomalus strains S80, S115, and S116 were identified as Endomyces fibuligera, Pichia onychis, and Pichia subpelliculosa, respectively.

The genetic identification using ITS or D1/D2 primers for marine yeasts gives reliable identification up to the species level but cannot distinguish between strains. Hence, a phenotyping microarray identification method (YT Plates) was applied. Table 4 shows the oxidation ability of the yeast isolates on 35 different substrates. Differences in substrate utilization were recorded within the isolates of the same species. For example, C. viswanathii isolate S8 was able to oxidize mannitol, but isolate S1 was not able to oxidize mannitol, whereas isolates S7 and S10 recorded weak oxidation. For $S$. cerevisiae isolates, there was a difference in oxidation results between the reference strain (NCYC 2592) and marine-derived yeasts. However, there 
Table 3. Identification outcome of 17 marine yeast isolates using ITS and D1/D2 primers and YT MicroPlate.

\begin{tabular}{|c|c|c|c|c|c|c|}
\hline \multirow[t]{2}{*}{ Isolate source } & \multirow[t]{2}{*}{ Sample } & \multirow[t]{2}{*}{ Strain } & \multicolumn{2}{|c|}{$\begin{array}{l}\text { Genetic identification } \\
\text { (ITS \& D1/D2 primers) }\end{array}$} & \multicolumn{2}{|c|}{$\begin{array}{l}\text { Biochemical identification } \\
\text { (TY Micro Plates) }\end{array}$} \\
\hline & & & Genus & Species & Genus & Species \\
\hline \multirow{4}{*}{$\begin{array}{l}\text { Medit. Sea. } \\
\text { Alexandria, Egypt }\end{array}$} & \multirow[t]{4}{*}{ A } & S 1 & Candida & viswanathii & Hyphopichia & burtonii C \\
\hline & & S 7 & Candida & viswanathii & Rhodotorula & acheniorum \\
\hline & & S 8 & Candida & viswanathii & Candida & parapsilosis $B$ \\
\hline & & S 10 & Candida & viswanathii & N/A & $\mathrm{N} / \mathrm{A}$ \\
\hline $\begin{array}{l}\text { Red Sea. } \\
\text { Ismailia, Egypt }\end{array}$ & $\mathrm{D}$ & S 45 & Candida & tropicalis & Candida & albicans \\
\hline \multirow{3}{*}{$\begin{array}{l}\text { Irish Sea. } \\
\text { Wales, } \\
\text { U.K. }\end{array}$} & E & S 57 & Candida & tropicalis & Candida & albicans \\
\hline & \multirow[t]{2}{*}{$\mathrm{F}$} & S 62 & Candida & tropicalis & $\mathrm{N} / \mathrm{A}$ & $\mathrm{N} / \mathrm{A}$ \\
\hline & & S 68 & Candida & tropicalis & Candida & albicans \\
\hline \multirow{9}{*}{$\begin{array}{l}\text { English Channel. } \\
\text { Plymouth, } \\
\text { U.K. }\end{array}$} & \multirow[t]{3}{*}{ G } & S 69 & Saccharomyces & cerevisiae & $\mathrm{N} / \mathrm{A}$ & $\mathrm{N} / \mathrm{A}$ \\
\hline & & S 71 & Saccharomyces & cerevisiae & Kluyveromyces & marxianus \\
\hline & & S 80 & Wickerhamomyces & anomalus & Endomyces & fibuligera \\
\hline & \multirow[t]{2}{*}{$\mathrm{H}$} & S 83 & Pichia & kudriavzevii & $\mathrm{N} / \mathrm{A}$ & $\mathrm{N} / \mathrm{A}$ \\
\hline & & S 84 & Candida & glabrata & $\mathrm{N} / \mathrm{A}$ & $\mathrm{N} / \mathrm{A}$ \\
\hline & \multirow[t]{2}{*}{$\mathrm{J}$} & S 115 & Wickerhamomyces & anomalus & Pichia & onychis \\
\hline & & S 116 & Wickerhamomyces & anomalus & Pichia & subpelliculosa \\
\hline & \multirow[t]{2}{*}{ K } & S 117 & Saccharomyces & cerevisiae & Saccharomyces & boulardii \\
\hline & & S 118 & Saccharomyces & cerevisiae & Saccharomyces & boulardii \\
\hline
\end{tabular}

were also differences in the oxidation results among the marine yeast, indicating that we possessed different strains of $S$. cerevisiae. In general, results suggested that all isolates could utilize glucose and inulin. Sucrose could be utilized by all strains except $C$. glabrata and P. kudriavzevii. Table 5 shows the differences in the assimilation capability of these yeasts on 65 different substrates. Similar to the results obtained from the oxidation tests, the assimilation ability of the yeast isolates varied within the same species.

Identification results obtained from both methods suggested that similar species of marine yeasts and terrestrial yeast are genetically similar but differ phenotypically. This would explain the marine environmental impact on the yeast, as most marine yeasts have a terrestrial origin and reached a marine environment through wind, rivers, or human activity.

\section{Discussion}

The samples used for marine yeast isolation in the current study were collected from coastal water within a $1 \mathrm{~m}$ depth. Near-shore was chosen as a location for sampling in this study because it was expected to contain a larger number of yeasts compared with off-shore sites [1,23] and to have a higher possibility of obtaining marine yeasts with potential characteristics for industrial application. Most reported marine yeast isolation methods were carried out using fresh samples (e.g., usually within 2 days of sampling), to avoid the reduction of yeast cell number in the sample $[8,39]$. This limited the potential of finding novel yeast strains from marine samples out of the local area as well as studies requiring samples from diverse marine habitats. The new isolation protocol reported in this study successfully overcame this limiting factor and maintained a high number and variety of yeast strains. It has been reported that filamentous fungi are present in high numbers in samples taken near the shore [8]. This was confirmed by the results obtained in this study, since filamentous fungal colonies were observed from 10 out of 14 marine samples when Kutty's method was used. Kutty's method utilizes Wickerham's yeast medium, which is a rich medium suitable for mold growth as well as for yeasts. There was no yeast, bacterial, or fungal growth when Dinesh's method was used for isolation. This was probably due to the small volume of the samples $(1 \mathrm{ml})$ recommended by the Dinesh method as well as the samples being old. It was reported that near-shore seawater samples only contain 10-10,000 yeast cells per liter [8, 23]. Therefore, 
A

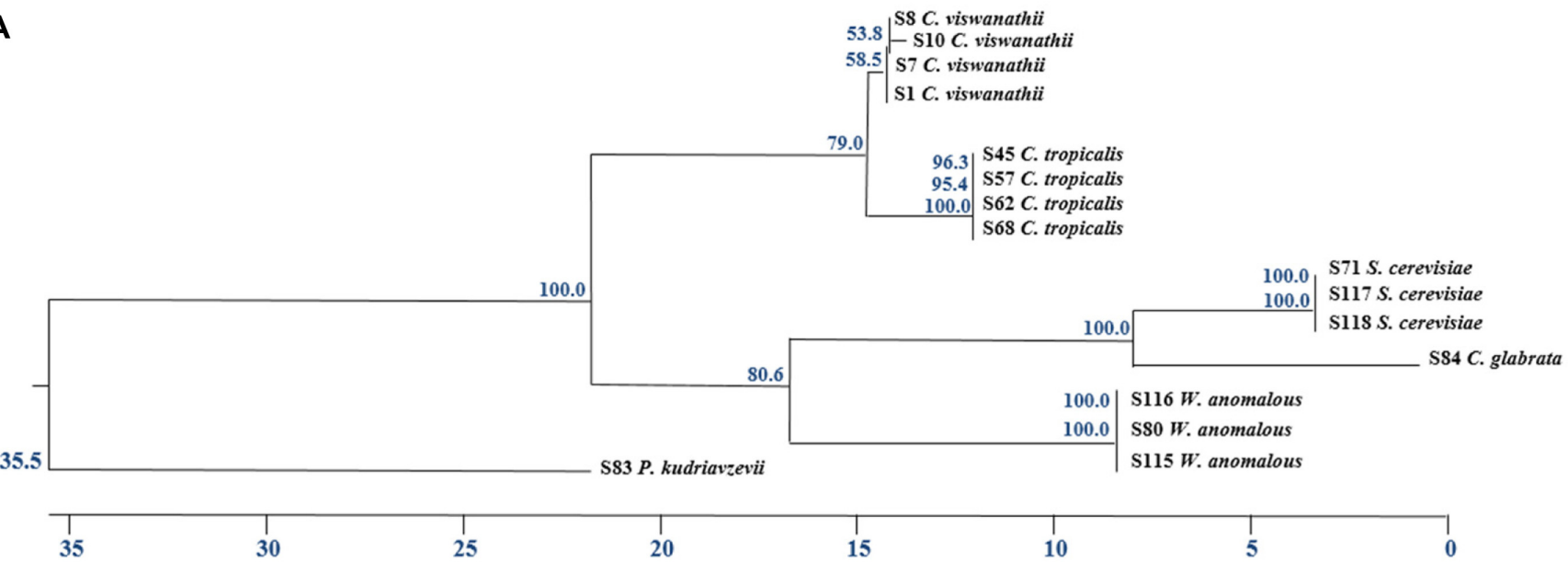

B

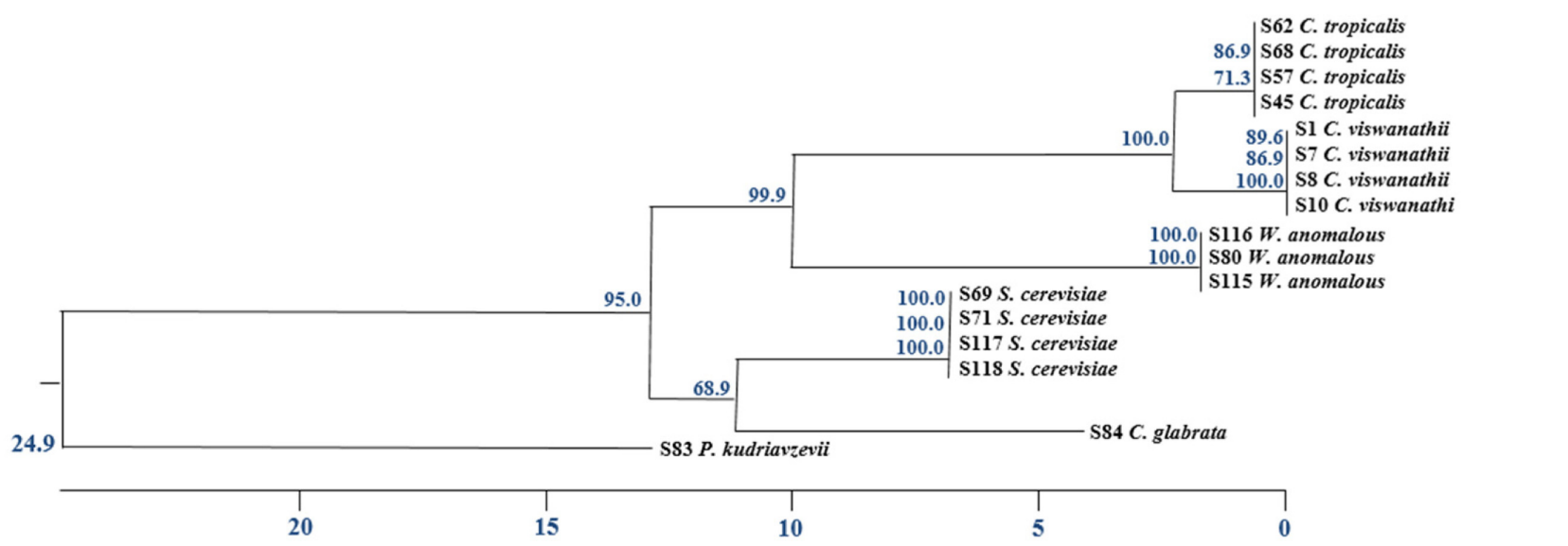

Fig. 4. Phylogenetic tree of the new marine yeasts.

The phylogram was calculated from the divergence in large-subunit region D1/D2 (A) and ITS region (B). Branch lengths are proportional to nucleotide differences, as indicated on the marker bar. Numbers given on branches are the frequencies (expressed as percentages) with which a branch appeared in 100 bootstrap replicates. Frequencies under $50 \%$ are not shown.

$1 \mathrm{ml}$ of the sample may not contain any yeast cells for isolation. Table 6 compares the three isolation methods used in this study.

The fact that our new isolation method generated a large number of pure yeast colonies from relatively old samples was mainly because of the three enrichment cycles. Generally, filamentous fungi propagate slower than yeasts. The incubation period in fermentations using filamentous fungi is generally $3-7$ days; while using yeasts it is normally 1-2 days [5, 27]. In the new marine yeast isolation method, the subculturing time was selected to be 2 days so that molds did not have enough time to increase their number. Thus, when the enriched culture was used to inoculate the next enrichment cycle, the number of molds was reduced. Throughout the three cycles of enrichment step, the reproduction of filamentous fungi was prevented, while a rapid yeast growth was maintained.

In our new isolation method, $30^{\circ} \mathrm{C}$ was used for the cell growth, which is relatively higher than the normal temperature of seawater. This was due to the following two considerations: (i) a relatively higher temperature like $30^{\circ} \mathrm{C}$ is preferable for industrial application. A high temperature would lead to faster fermentation rates and therefore higher productivity; (ii) it has been demonstrated that although marine yeast strains' usual temperature is relatively low, their optimum growth temperature could be higher. Kutty [22] studied the effect of temperature on the growth of marine yeasts obtained from slope sediments of the Arabian Sea at different depths (up to $100 \mathrm{~m}$ ), where the temperatures range at $6-16^{\circ} \mathrm{C}$, and concluded that the maximum growth was $30^{\circ} \mathrm{C}$ in almost all isolates.

Our new method for marine yeast isolation was easy 
Table 4. Comparison of oxidation tests (using YT plates for yeast identification) of 17 marine yeast isolates and the terrestrial S. cerevisiae NCYC 2592.

\begin{tabular}{|c|c|c|c|c|c|c|c|c|c|c|c|c|c|c|c|c|c|c|}
\hline \multirow[b]{3}{*}{$\begin{array}{l}\text { Oxidation test } \\
\text { (substrate) }\end{array}$} & \multicolumn{18}{|c|}{ Yeast strains } \\
\hline & \multicolumn{5}{|c|}{ S. cerevisiae } & \multicolumn{4}{|c|}{ C. tropicalis } & \multicolumn{4}{|c|}{ C. viswanathii } & \multicolumn{3}{|c|}{ W. anomalus } & \multirow{2}{*}{$\begin{array}{c}\text { C. glabrata } \\
\text { S } 84\end{array}$} & \multirow{2}{*}{$\frac{\text { P. kudriavzevii }}{\text { S } 83}$} \\
\hline & Ref & S69 & S71 & S117 & S118 & $\mathrm{S} 45$ & S57 & S62 & S68 & $\mathrm{S} 1$ & S7 & S8 & $\mathrm{S} 10$ & $\mathrm{~S} 80$ & S115 & S116 & & \\
\hline D-Cellobiose & - & - & - & - & - & - & - & - & - & - & - & - & - & $\mathrm{w}$ & $\mathrm{w}$ & $\mathrm{w}$ & - & - \\
\hline $\begin{array}{l}\text { N-Acetyl-D- } \\
\text { glocosamine }\end{array}$ & - & - & - & - & - & $\mathrm{w}$ & + & $\mathrm{w}$ & $\mathrm{w}$ & - & $\mathrm{w}$ & + & $\mathrm{w}$ & - & - & - & - & - \\
\hline Acetic acid & - & - & - & - & - & - & - & - & - & - & - & - & - & - & - & - & - & - \\
\hline Gentiobiose & - & - & - & - & - & - & - & - & - & - & - & - & - & - & $\mathrm{w}$ & - & $\mathrm{w}$ & - \\
\hline$\alpha$-D-Glucose & + & + & + & + & + & + & + & + & + & + & + & + & + & + & + & + & + & + \\
\hline Formic acid & - & - & - & - & - & - & - & - & - & - & - & - & - & - & - & - & - & - \\
\hline Maltose & + & - & - & + & + & + & + & + & + & + & + & + & + & + & $\mathrm{w}$ & + & $\mathrm{w}$ & - \\
\hline Propionic acid & - & - & - & - & - & - & - & - & - & - & - & - & - & - & - & - & - & - \\
\hline Maltotriose & - & - & - & - & - & $\mathrm{w}$ & + & $\mathrm{w}$ & $\mathrm{w}$ & + & + & + & + & + & + & + & $\mathrm{w}$ & - \\
\hline D-Psicose & - & - & $\mathrm{w}$ & - & $\mathrm{w}$ & - & $\mathrm{w}$ & - & - & - & - & $\mathrm{w}$ & $\mathrm{w}$ & - & $\mathrm{w}$ & - & $\mathrm{w}$ & - \\
\hline Succinic acid & - & - & - & - & - & - & - & - & - & - & $\mathrm{w}$ & $\mathrm{w}$ & $\mathrm{w}$ & - & - & - & - & - \\
\hline D-Melezitose & - & - & - & - & - & - & $\mathrm{w}$ & $\mathrm{w}$ & - & - & $\mathrm{w}$ & $\mathrm{w}$ & $\mathrm{w}$ & $\mathrm{w}$ & + & $\mathrm{w}$ & - & - \\
\hline L-Sorbose & - & - & - & - & - & - & - & - & - & - & - & - & - & - & $\mathrm{w}$ & - & $\mathrm{w}$ & - \\
\hline $\begin{array}{l}\text { Succinic acid } \\
\text { mono-methyl ester }\end{array}$ & - & - & - & - & - & - & - & - & - & - & - & $\mathrm{w}$ & $\mathrm{w}$ & - & - & - & - & - \\
\hline D-Melezitose & - & - & - & - & - & - & - & - & - & - & - & - & - & - & $\mathrm{w}$ & - & $\mathrm{w}$ & - \\
\hline Salicin & - & - & - & - & - & - & - & - & - & - & - & - & $\mathrm{w}$ & $\mathrm{w}$ & + & + & $\mathrm{w}$ & - \\
\hline L-Aspartic acid & - & - & - & - & - & - & - & - & - & - & - & $\mathrm{w}$ & - & - & - & - & - & - \\
\hline Palatinose & - & + & + & - & - & + & + & + & + & - & $\mathrm{w}$ & $\mathrm{w}$ & $\mathrm{w}$ & $\mathrm{w}$ & + & $\mathrm{w}$ & $\mathrm{w}$ & - \\
\hline L-Glutamic acid & - & - & - & - & - & - & - & - & - & - & - & - & - & - & - & - & $\mathrm{w}$ & - \\
\hline D-Raffinose & $\mathrm{w}$ & + & + & + & + & - & - & - & - & - & - & - & - & + & + & + & $\mathrm{w}$ & - \\
\hline D-Sorbitol & - & - & - & - & - & + & $\mathrm{w}$ & $\mathrm{w}$ & $\mathrm{w}$ & $\mathrm{w}$ & $\mathrm{w}$ & + & $\mathrm{w}$ & - & $\mathrm{w}$ & - & $\mathrm{w}$ & - \\
\hline L-Proline & - & - & - & - & - & - & - & $\mathrm{w}$ & - & $\mathrm{w}$ & $\mathrm{w}$ & + & $\mathrm{w}$ & - & $\mathrm{w}$ & - & - & - \\
\hline Stachyose & $\mathrm{w}$ & - & $\mathrm{w}$ & $\mathrm{w}$ & $\mathrm{w}$ & - & - & - & - & - & - & - & - & - & $\mathrm{w}$ & - & $\mathrm{w}$ & - \\
\hline D-Arabitol & - & - & - & - & - & - & - & - & - & - & - & - & $\mathrm{w}$ & - & $\mathrm{w}$ & - & $\mathrm{w}$ & - \\
\hline D-Gluconic acid & - & - & - & - & - & - & - & - & - & - & - & $\mathrm{w}$ & - & - & - & - & - & - \\
\hline Sucrose & + & + & + & + & + & + & + & + & + & + & + & + & + & + & + & + & - & - \\
\hline Xylitol & - & - & - & - & - & - & - & - & - & - & - & - & - & - & $\mathrm{w}$ & - & $\mathrm{w}$ & - \\
\hline Dextrin & - & - & $\mathrm{w}$ & - & $\mathrm{w}$ & $\mathrm{w}$ & $\mathrm{w}$ & $\mathrm{w}$ & - & $\mathrm{w}$ & $\mathrm{w}$ & $\mathrm{w}$ & $\mathrm{w}$ & $\mathrm{w}$ & $\mathrm{w}$ & - & $\mathrm{w}$ & - \\
\hline D-Trehalose & - & - & - & $\mathrm{w}$ & - & + & + & + & + & - & - & $\mathrm{w}$ & - & - & $\mathrm{w}$ & - & + & - \\
\hline Glycerol & - & - & - & - & - & - & - & - & - & - & - & - & - & - & $\mathrm{w}$ & - & $\mathrm{w}$ & - \\
\hline Inulin & + & + & + & + & + & + & + & + & + & + & + & + & + & + & + & + & + & + \\
\hline Turanose & + & - & - & + & + & + & + & + & + & $\mathrm{w}$ & $\mathrm{w}$ & + & + & + & + & + & - & - \\
\hline Tween 80 & - & - & - & - & - & - & - & - & - & - & - & - & - & - & - & - & - & - \\
\hline
\end{tabular}

"+" means positive response, "-" means negative response, and " $w$ " means weak positive response.

when applied to either liquid or solid marine samples. This method took 8-10 days to obtain a large number of pure yeast colonies. It was successfully applied to samples up to 2 weeks old, so fresh samples are not necessary. This 
Table 5. Comparison of assimilation tests (using YT plates for yeast identification) of 17 marine yeast isolates and the terrestrial S. cerevisiae NCYC 2592.

\begin{tabular}{|c|c|c|c|c|c|c|c|c|c|c|c|c|c|c|c|c|c|c|}
\hline \multirow[b]{3}{*}{$\begin{array}{l}\text { Assimilation test } \\
\text { (substrate) }\end{array}$} & \multicolumn{18}{|c|}{ Yeast Strains } \\
\hline & \multicolumn{5}{|c|}{ S. cerevisiae } & \multicolumn{4}{|c|}{ C. tropicalis } & \multicolumn{4}{|c|}{ C. viswanathii } & \multicolumn{3}{|c|}{ W. anomalus } & \multirow{2}{*}{$\begin{array}{c}\text { C. glabrata } \\
\text { S } 84\end{array}$} & \multirow{2}{*}{$\frac{\text { P. kudriavzevii }}{\text { S } 83}$} \\
\hline & Ref & S69 & S71 & S117 & S118 & $\mathrm{S} 45$ & S57 & $\mathrm{S} 62$ & S68 & $\mathrm{S} 1$ & S7 & S8 & $\mathrm{S} 10$ & S80 & S115 & S116 & & \\
\hline D-Cellobiose & - & - & - & - & - & - & - & - & - & - & - & - & - & $\mathrm{w}$ & $\mathrm{w}$ & $\mathrm{w}$ & - & - \\
\hline $\begin{array}{l}\text { N-Acetyl-D- } \\
\text { glucosamine }\end{array}$ & - & - & - & - & - & + & + & + & + & $\mathrm{w}$ & $\mathrm{w}$ & + & $\mathrm{w}$ & - & - & - & - & - \\
\hline Maltitol & - & - & - & - & - & $\mathrm{w}$ & $\mathrm{w}$ & $\mathrm{w}$ & $\mathrm{w}$ & - & - & $\mathrm{w}$ & - & $\mathrm{w}$ & $\mathrm{w}$ & $\mathrm{w}$ & - & - \\
\hline D-Xylose & - & - & - & - & - & - & - & - & - & - & $\mathrm{w}$ & - & $\mathrm{w}$ & - & - & - & - & - \\
\hline Fumaric acid & - & - & - & - & - & $\mathrm{w}$ & $\mathrm{w}$ & $\mathrm{w}$ & $\mathrm{w}$ & $\mathrm{w}$ & $\mathrm{w}$ & $\mathrm{w}$ & $\mathrm{w}$ & - & - & - & - & - \\
\hline Gentiobiose & - & - & - & - & - & - & - & - & - & - & - & - & - & - & $\mathrm{w}$ & $\mathrm{w}$ & - & - \\
\hline D-Glucosamine & - & - & - & - & - & - & - & - & - & - & - & - & $\mathrm{w}$ & - & - & - & - & - \\
\hline D-Mannitol & - & - & - & - & - & $\mathrm{w}$ & $\mathrm{w}$ & + & + & - & $\mathrm{w}$ & $\mathrm{w}$ & $\mathrm{w}$ & - & $\mathrm{w}$ & $\mathrm{w}$ & - & - \\
\hline Succinic acid + D-xylose & - & - & - & - & - & - & - & - & - & $\mathrm{w}$ & $\mathrm{w}$ & $\mathrm{w}$ & $\mathrm{w}$ & - & $\mathrm{w}$ & $\mathrm{w}$ & - & $\mathrm{w}$ \\
\hline L-Malic acid & - & - & - & - & - & $\mathrm{w}$ & $\mathrm{w}$ & $\mathrm{w}$ & $\mathrm{w}$ & $\mathrm{w}$ & $\mathrm{w}$ & $\mathrm{w}$ & $\mathrm{w}$ & - & - & - & - & - \\
\hline Maltose & + & - & - & + & + & + & + & + & + & + & + & + & + & + & + & + & - & - \\
\hline$\alpha$-D-glucose & + & + & + & + & + & + & + & + & + & + & + & + & + & + & + & + & + & + \\
\hline D-Sorbitol & - & - & - & - & - & $\mathrm{w}$ & - & $\mathrm{w}$ & $\mathrm{w}$ & - & - & $\mathrm{w}$ & - & - & $\mathrm{w}$ & - & - & - \\
\hline $\begin{array}{l}\text { N-Acetyl-L-glutamic } \\
\text { acid + D-xylose }\end{array}$ & - & - & - & - & - & - & - & - & - & - & $\mathrm{w}$ & $\mathrm{w}$ & $\mathrm{w}$ & - & - & - & - & - \\
\hline $\begin{array}{l}\text { Succinic acid } \\
\text { mono-methyl ester }\end{array}$ & - & - & - & - & - & $\mathrm{w}$ & - & - & - & - & - & + & - & - & - & - & - & - \\
\hline Maltotriose & - & - & - & - & - & + & + & + & + & + & + & + & + & + & + & + & - & - \\
\hline D-Galactose & + & + & + & + & + & + & $\mathrm{w}$ & $\mathrm{w}$ & $\mathrm{w}$ & $\mathrm{w}$ & $\mathrm{w}$ & $\mathrm{w}$ & $\mathrm{w}$ & - & $\mathrm{w}$ & $\mathrm{w}$ & - & - \\
\hline Adonitol & - & - & - & - & - & $\mathrm{w}$ & $\mathrm{w}$ & $\mathrm{w}$ & $\mathrm{w}$ & - & $\mathrm{w}$ & $\mathrm{w}$ & $\mathrm{w}$ & - & $\mathrm{w}$ & - & - & - \\
\hline Quinic acid + D-xylose & - & - & - & - & - & - & - & - & - & - & - & - & - & - & $\mathrm{w}$ & - & - & - \\
\hline Bromosuccinic acid & - & - & - & - & - & - & - & - & - & - & - & - & - & - & - & - & - & - \\
\hline D-Melezitose & - & - & - & - & - & $\mathrm{w}$ & $\mathrm{w}$ & $\mathrm{w}$ & $\mathrm{w}$ & $\mathrm{w}$ & $\mathrm{w}$ & $\mathrm{w}$ & - & $\mathrm{w}$ & $\mathrm{w}$ & $\mathrm{w}$ & - & - \\
\hline D-Psicose & - & - & - & - & - & - & - & - & - & - & - & - & - & - & - & - & - & - \\
\hline D-Arabitol & - & - & - & - & - & - & - & - & - & - & - & - & - & - & $\mathrm{w}$ & - & - & - \\
\hline D-Glucuronic acid & - & - & - & - & - & - & - & - & - & - & - & - & - & - & - & - & - & - \\
\hline D-xylose & & & & & & & & & & & & & & & & & & \\
\hline L-Glutamic acid & - & - & - & - & - & $\mathrm{w}$ & $\mathrm{w}$ & $\mathrm{w}$ & - & - & - & - & - & - & - & - & - & - \\
\hline D-melibiose & - & - & - & - & - & - & - & - & - & - & - & - & - & - & - & - & - & - \\
\hline L-rhamnose & - & - & - & - & - & - & - & - & - & - & - & - & - & - & - & - & - & - \\
\hline Xylitol & - & - & - & - & - & - & - & - & - & - & - & - & - & - & - & - & - & - \\
\hline Dextrin + D-xylose & - & - & - & - & - & $\mathrm{w}$ & - & - & - & - & $\mathrm{w}$ & $\mathrm{w}$ & $\mathrm{w}$ & - & - & $\mathrm{w}$ & - & - \\
\hline$\gamma$-Aminobutyric acid & - & - & - & - & - & $\mathrm{w}$ & $\mathrm{w}$ & $\mathrm{w}$ & $\mathrm{w}$ & - & - & - & - & - & - & - & - & - \\
\hline Palatinose & - & + & + & - & - & + & + & + & + & $\mathrm{w}$ & - & + & + & $\mathrm{w}$ & $\mathrm{w}$ & $\mathrm{w}$ & - & - \\
\hline L-Sorbose & - & - & - & - & - & - & - & - & - & - & - & - & - & - & - & - & - & - \\
\hline i-Erythritol & - & - & - & - & - & - & - & - & - & - & - & - & - & - & - & $\mathrm{w}$ & - & - \\
\hline$\alpha$-D-Lactose + D-xylose & - & - & - & - & - & - & - & - & - & - & $\mathrm{w}$ & - & $\mathrm{w}$ & - & $\mathrm{w}$ & - & - & - \\
\hline$\alpha$-Ketoglutamic acid & - & - & - & - & - & $\mathrm{w}$ & $\mathrm{w}$ & $\mathrm{w}$ & $\mathrm{w}$ & - & - & - & - & - & - & - & - & - \\
\hline D-Raffinose & $\mathrm{w}$ & $\mathrm{w}$ & $\mathrm{w}$ & $\mathrm{w}$ & $\mathrm{w}$ & - & - & - & - & - & - & - & - & $\mathrm{w}$ & + & + & $\mathrm{w}$ & - \\
\hline
\end{tabular}


Table 5. Continued.

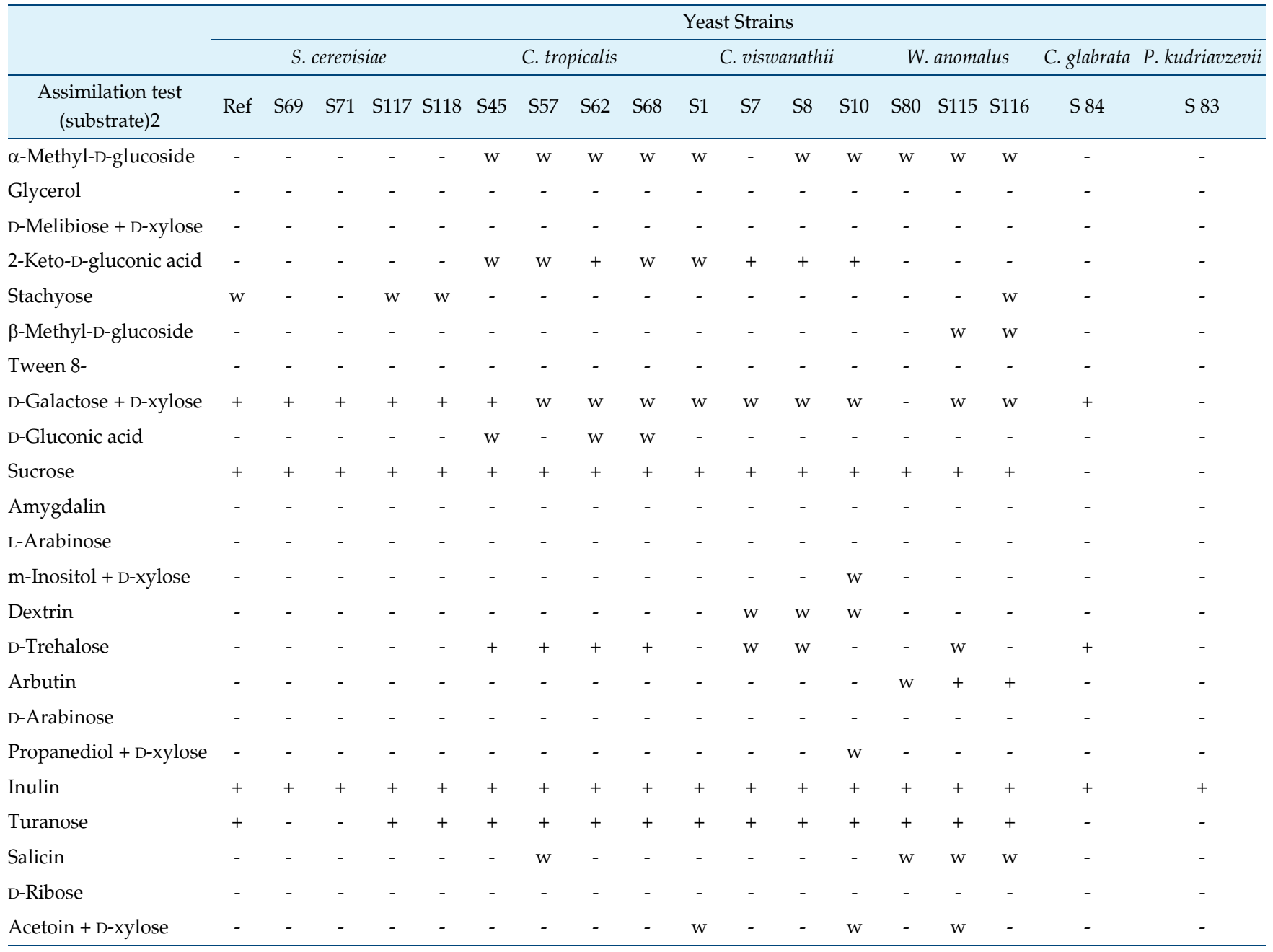

methodology allows for the isolation of yeasts that are present at very low numbers in the original sample.

\section{Screening and Metabolism Evaluation Using Phenotypic Microarray Assay}

Conversion of monomeric sugars into commercially valuable products is a desirable trait for any yeast strain for potential industrial application. In this study, PM assays have been used to screen for novel marine-derived yeasts with high capability for the utilization of the monomeric sugars, including glucose, xylose, galactose, and mannitol, in a seawater-based medium. S. cerevisiae NCYC 2592, a strain that has high metabolism capacity and high tolerance to a wide range of inhibitors presented in the lignocellulosic hydrolysate [29, 44], was also used in the PM assays as a control to evaluate the isolated marine yeast for their metabolism capacity. The results showed that
S. cerevisiae NCYC 2592 grew well in the seawater-based medium. However, 11 marine isolates have been identified that performed better than S. cerevisiae NCYC 2592 in terms of glucose utilization in seawater-based media. This may be due to the fact that the marine yeasts acquired high tolerance to salts and other inhibitors, which exist in seawater; therefore, their growth was not disturbed by the presence of high level of salts in the medium. As expected, the xylose utilization experiments revealed that the reference strain did not grow [40,44]. However, many of our marine isolates showed good xylose utilization and they could be potential candidates for bioethanol fermentations using xylose as the substrate.

Isolating yeast strains with the capacity for utilizing mannitol is of particular interest. Mannitol is considered as the most abundant sugar alcohol in nature [2] and has been highlighted as a potential bulk marine sugar [33] as it is 
Table 6. Comparison of the three marine yeast isolation methods used in this study.

\begin{tabular}{llll}
\hline & \multicolumn{1}{c}{ Zaky's method (developed in this study) } & \multicolumn{1}{c}{ Kutty's method $^{\mathrm{a}}$} & \multicolumn{1}{c}{ Dinesh's method $^{\mathrm{b}}$} \\
\hline Sample preparation & $\begin{array}{l}\text { Enrichment } \\
\text { 3 cycles }(48 \mathrm{~h} \text { each) }\end{array}$ & $\begin{array}{l}\text { Filtration } \\
\text { filters }(0.45 \mu \mathrm{m})\end{array}$ & - \\
Media $^{\mathrm{c}}$ & $\begin{array}{l}\text { Zaky's media } \\
\text { (enrichment, isolation broth, isolation agar) }\end{array}$ & Wickerham's medium & Sabouraud's Dextrose Agar \\
Antibiotic & Penicillin $\mathrm{G}+$ streptomycin sulfate & Chloramphenicol & - \\
& $(500 \mathrm{mg} / \mathrm{l}$ each) & $(200 \mathrm{mg} / \mathrm{l})$ & 5.6 \\
$\mathrm{pH}$ & 5.0 & 7.0 & $35^{\circ} \mathrm{C}$ \\
Incubation temp. & $30^{\circ} \mathrm{C}$ & $18 \pm 2^{\circ} \mathrm{C}$ & 4 days \\
Total time & 10 days & 16 days & $1 \mathrm{~g}$ \\
Sample size & $10 \mathrm{~g}$ or $100 \mathrm{ml}$ & $30 \mathrm{ml}$ & New samples only \\
Sample & Up to 2-week-old samples & New samples only & Very low \\
Number of isolates & Very high & Low & Not specific \\
Specificity & Specific to yeasts & Specific to fungi & Fresh solid samples \\
Applicability & Suitable for both liquid and solid marine samples & Fresh liquid samples & \\
\hline
\end{tabular}

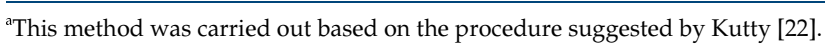

${ }^{b}$ This method was carried out based on the procedure suggested by Dinesh et al. [7].

${ }^{\mathrm{c}}$ Detailed medium composition is reported in Materials and Methods.

found in different types of marine algae, such as brown and golden algae, and red algae [14]. PM assay results revealed that $S$. cerevisiae NCYC 2592 cannot utilize mannitol. Many marine yeasts isolated in the current study had high mannitol utilization, especially isolate $S 45$, which showed the highest mannitol consumption; this strain may have potential to be used as an industrial strain for converting mannitol to value-added products. It was reported that mannitol is rapidly metabolized by bacteria in marine habitats [17]. White et al. [42] suggested that several herbivorous fish cannot assimilate mannitol directly but it can be utilized as an indirect nutrient via fermentation in the hindgut. It has been reported that mannitol plays an osmoregulatory role in algae that experiences significant changes in salinity $[2,14]$. Therefore, we suggest that marine yeast that are able to ferment mannitol are of particular importance as candidates for marine fermentation (fermentations that use marine yeast, marine biomass, and seawater), not only because mannitol is widely available in marine biomass but also because mannitol is expected to weaken the inhibitory effects of seawater's salinity.

Galactose is another sugar that is present in marine biomass substrates, such as red seaweed [18]. Isolate S45 showed the highest utilization level among the marine isolates and was higher than the reference strain. This makes it a potential candidate for bioethanol production from marine substrates such as seaweed. Galactose utilization is of particular interest as most yeast galactose utilization is suppressed by the presence of glucose [30], and research may lead to identification of marine yeast that are capable of efficient utilization of both glucose and galactose simultaneously.

Biomass hydrolysates are characterized by a complex mixture of sugars. Efficient conversion of these sugars into end-metabolites has been highlighted as a desirable phenotype. PM assays revealed that marine-derived yeasts have good overall sugar utilization capabilities, and several marine yeast isolates have the capacity for utilizing all four of these sugars.

Fresh water is traditionally used in fermentations. However, many parts of the world struggle to produce enough potable water for human consumption. There are only limited studies using seawater for fermentation [24]. PM assays revealed that the sugar utilization by marine yeasts was almost identical after $24 \mathrm{~h}$ of incubation in experiments using seawater and using fresh water. These results indicated that the presence of salt was not deleterious to sugar utilization by marine yeasts.

\section{Genetic Identification of Marine Yeast Isolates and Phenotypic Characterization}

New isolates of marine yeasts were identified using the same procedures as used for terrestrial yeasts, as no specific procedure for marine yeast identification has yet been reported. Genetic identification methods (ITS and 
D1/D2) successfully identified our marine-derived yeasts and that proves they have terrestrial origin (as they share the same genotype). This finding supported previous reports that the majority of marine yeasts, including those isolated from deep-sea regions, are not indigenous [3, 16]. We found that genus Candida was more common in the marine environment compared with other yeast genera, which agrees with several previous studies $[9,34]$. S. cerevisiae, C. tropicalis, W. anomalus, and C. glabrata were previously isolated from different marine habitats $[12,28]$. C. viswanathii was recently isolated from deep-sea hydrothermal animals [3]. P. kudriavzevii has not previously been isolated from a marine environment.

In this study, the identification of the 17 isolates using YT MicroPlate did not match the genetic identification (Table 3). This could be due to the fact that the Biolog database was based on substrate utilization by terrestrial yeast strains only. YT Biolog is commercially available and is a mature method for yeast identification [31, 32]. It was reported that 49 out of 72 yeasts that have been isolated from foods and beverages were correctly identified using the Biolog system [32]. However, in order to obtain a valid identification, a large database is needed. Marine yeasts have inherited new characteristics for living in a marine habitat and so have altered phenotypes. This means that available biochemical-based identification methods such as YT Biolog plates maybe not be suitable for identification of marine yeasts using the terrestrial yeast-based database. Foschino et al. [10] reported that MicroPlate YT Biolog failed to identify yeast isolates from sourdough samples probably because their database was based on clinical yeast isolates. If an intensive database could be built based on substrate utilization in marine yeasts, the YT Biolog plate could be used for marine yeast identification as well.

In general, identification using sequence data has been shown to be more robust than using phenotypic data. However, it has been useful in highlighting the metabolic requirements of marine microorganisms with interesting industrial capabilities [37]. The advancement of the D1/D2 and ITS database in GenBank (http://www.ncbi.nlm.nih.gov/ genbank) allows laboratories around the world to easily and accurately identify more yeast species. Furthermore, phylogenetic analysis of the gene sequences is leading to a major modification of yeast systematics that will result in redefinition of almost all genera [21]. It is worth mentioning that the PM screening assay revealed that several marine yeast isolates had the capacity for utilizing xylose or mannitol (Fig. 3). However, use of YT MicroPlate revealed no utilization of these compounds (Tables 4 and
5). This inconsistency could be due to the differences of the culturing conditions, including the concentrations of the tested sugars, the incubation temperature, and the inoculation level. In addition, the PM assay used liquid media whereas the YT MicroPlate used solid media.

In conclusion, the limited availability of marine yeast strains is one of the key challenges that restricts the development of a marine-yeast-based industry. This work developed an efficient and selective method for marine yeast isolation. Using this method, 116 marine yeast isolates were selected from 14 marine samples collected from different regions around the world. These isolates were then screened for their sugar utilization ability. Seventeen strains representing the best utilizer for each sugar were subjected to identification using the PCR-based method. These 17 strains belonged to six different species, including P. kudriavzevii, which has not previously been reported as a marine yeast. Phenotypic microarray assay using YT Biolog MicroPlate was found to be a useful technique for strain discrimination but not for identification of marine yeasts.

\section{Acknowledgments}

The authors gratefully acknowledge the financial support by the Ministry of Higher Education of Egypt and Egyptian Cultural and Educational Bureau in London for Mr. Zaky's Scholarship. We also thank the Biotechnology and Biological Sciences Research Council (BBSRC) Sustainable Bioenergy Centre (BSBEC), under the programme for Lignocellulosic Conversion to Ethanol (LACE) (BB/G01616X/1), for supporting this research. Also, thanks to Dr. Deiaa Gad ElRab from Food Microbiology and Biotechnology Laboratory, North Carolina A\&T State University, USA, and Dr. Daniel White from Plymouth Marine Laboratory, UK, for collecting and sending some of the marine samples.

\section{References}

1. Ahearn DG, Roth FJ Jr, Meyers SP. 1968. Ecology and characterization of yeasts from aquatic regions of South Florida. Mar. Biol. 1: 291-308.

2. Bieleski RL. 1982. Sugar alcohols, pp. 158-192. In Loewus F, Tanner W (eds.). Plant Carbohydrates I. Springer, BerlinHeidelberg.

3. Burgaud G, Arzur D, Durand L, Cambon-Bonavita M-A, Barbier G. 2010. Marine culturable yeasts in deep-sea hydrothermal vents: species richness and association with fauna. FEMS Microbiol. Ecol. 73: 121-133.

4. Cadete R, Fonseca C, Rosa C. 2014. Novel yeast strains from 
Brazilian biodiversity: biotechnological applications in lignocellulose conversion into biofuels, pp. 255-279. In da Silva SS, Chandel AK (eds.). Biofuels in Brazil. Springer International Publishing.

5. Cavka A, Jönsson LJ. 2014. Comparison of the growth of filamentous fungi and yeasts in lignocellulose-derived media. Biocatal. Agric. Biotechnol. 3: 197-204.

6. Chi Z, Chi Z, Zhang T, Liu G, Li J, Wang X. 2009. Production, characterization and gene cloning of the extracellular enzymes from the marine-derived yeasts and their potential applications. Biotechnol. Adv. 27: 236-255.

7. Dinesh Kumar S, Karthik L, Gaurav Kumar, Bhaskara Rao KV. 2011. Biosynthesis of silver nanoparticles from marine yeast and their antimicrobial activity against multidrug resistant pathogens. Pharmacol. Online 3: 1100-1111.

8. Fell JW. 2001. Collection and identification of marine yeasts, pp. 347-356. Methods in Microbiology. Academic Press, Burlington.

9. Fell J, Statzell-Tallman A, Scorzetti G, Gutiérrez M. 2011. Five new species of yeasts from fresh water and marine habitats in the Florida Everglades. Antonie Van Leeuwenhoek 99: 533-549.

10. Foschino R, Gallina S, Andrighetto C, Rossetti L, Galli A. 2004. Comparison of cultural methods for the identification and molecular investigation of yeasts from sourdoughs for Italian sweet baked products. FEMS Yeast Res. 4: 609-618.

11. Greetham D, Wimalasena T, Kerruish DWM, Brindley S, Ibbett RN, Linforth RL, et al. 2014. Development of a phenotypic assay for characterisation of ethanologenic yeast strain sensitivity to inhibitors released from lignocellulosic feedstocks. J. Ind. Microbiol. Biotechnol. 41: 931-945.

12. Guo F-J, Ma Y, Xu H-M, Wang X-H, Chi Z-M. 2013. A novel killer toxin produced by the marine-derived yeast Wickerhamomyces anomalus YF07b. Antonie Van Leeuwenhoek 103: 737-746.

13. Jones EBG, Suetrong S, Sakayaroj J, Bahkali A, AbdelWahab MA, Boekhout T, Pang KL. 2015. Classification of marine Ascomycota, Basidiomycota, Blastocladiomycota and Chytridiomycota. Fungal Diver. 73: 1-72.

14. Karsten U, Barrow KD, Nixdorf O, West JA, King RJ. 1997. Characterization of mannitol metabolism in the mangrove red alga Caloglossa leprieurii (Montagne) J.Agardh. Planta 201: 173-178.

15. Khambhaty Y, Upadhyay D, Kriplani Y, Joshi N, Mody K, Gandhi MR. 2013. Bioethanol from macroalgal biomass: utilization of marine yeast for production of the same. Bioenergy Res. 6: 188-195.

16. Kohlmeyer J, Kohlmeyer E. 1979. Yeasts, pp. 556-606. In Kohlmeyer J, Kohlmeyer E (eds.). Marine Mycology Academic Press, New York.

17. Koop K, Carter RA, Newell RC. 1982. Mannitol-fermenting bacteria as evidence for export from kelp beds. Limnol. Oceanogr. 27: 950-954.
18. Kumar S, Gupta R, Kumar G, Sahoo D, Kuhad RC. 2013. Bioethanol production from Gracilaria verrucosa, a red alga, in a biorefinery approach. Bioresour. Technol. 135: 150-156.

19. Kurtzman CP, Fell J. 2006. Yeast systematics and phylogeny - implications of molecular identification methods for studies in ecology, pp. 11-30. In Péter G, Rosa C (eds.). Biodiversity and Ecophysiology of Yeasts. Springer, Berlin-Heidelberg.

20. Kurtzman C, Piškur J. 2006. Taxonomy and phylogenetic diversity among the yeasts, pp. 29-46. In Sunnerhagen P, Piskur J (eds.). Comparative Genomics. Springer, BerlinHeidelberg.

21. Kurtzman CP, Mateo RQ, Kolecka A, Theelen B, Robert V, Boekhout T. 2015. Advances in yeast systematics and phylogeny and their use as predictors of biotechnologically important metabolic pathways. FEMS Yeast Res. 15: fov050.

22. Kutty SN. 2009. Marine yeasts from the slope sediments of Arabian Sea and Bay of Bengal. PhD. Cochin University of Science and Technology, India.

23. Kutty SN, Philip R. 2008. Marine yeasts - a review. Yeast 25: 465-483.

24. Lin CSK, Luque R, Clark JH, Webb C, Du C. 2011. A seawater-based biorefining strategy for fermentative production and chemical transformations of succinic acid. Energy Environ. Sci. 4: 1471-1479.

25. Mitchell TG, White TJ, Taylor JW. 1992. Comparison of $5.8 \mathrm{~S}$ ribosomal DNA sequences among the basidiomycetous yeast genera Cystofilobasidium, Filobasidium and Filobasidiella. J. Med. Vet. Mycol. 30: 207-218.

26. Nagahama T, Hamamoto M, Nakase T, Horikoshi K. 1999. Kluyveromyces nonfermentans sp. nov., a new yeast species isolated from the deep sea. Int. J. Syst. Bacteriol. 49: 18991905.

27. Nasr NF, Zaky AS, Daw ZY. 2010. Microbiological quality of active dry and compressed baker's yeast sold in Egypt. J. Pure Appl. Microbiol. 4: 455-462.

28. Obara N, Oki N, Okai M, Ishida M, Urano N. 2015. Development of a simple isolation method for yeast Saccharomyces cerevisiae with high fermentative activities from coastal waters. Stud. Sci. Technol. 4: 71-76.

29. Oshoma CE, Greetham D, Louis EJ, Smart KA, Phister TG, Powell C, Du C. 2015. Screening of non-Saccharomyces cerevisiae strains for tolerance to formic acid in bioethanol fermentation. PLoS One 10: e0135626.

30. Ostergaard S, Olsson L, Johnston M, Nielsen J. 2000. Increasing galactose consumption by Saccharomyces cerevisiae through metabolic engineering of the GAL gene regulatory network. Nat. Biotechnol. 18: 1283-1286.

31. Pincus DH, Orenga S, Chatellier S. 2007. Yeast identification - past, present, and future methods. Med. Mycol. 45: 97-121.

32. Praphailong W, Van Gestel M, Fleet GH, Heard GM. 1997. Evaluation of the Biolog system for the identification of food and beverage yeasts. Lett. Appl. Microbiol. 24: 455-459.

33. Reed RH, Davison IR, Chudek JA, Foster R. 1985. The 
osmotic role of mannitol in the Phaeophyta: an appraisal. Phycologia 24: 35-47.

34. Rhishipal R, Philip R. 1998. Selection of marine yeasts for the generation of single cell protein from prawn-shell waste. Bioresour. Technol. 65: 255-256.

35. Sarkar S, Pramanik A, Mitra A, Mukherjee J. 2010. Bioprocessing data for the production of marine enzymes. Mar. Drugs 8: 1323-1372.

36. Seshadri R, Sieburth JM. 1975. Seaweeds as a reservoir of Candida yeasts in inshore waters. Mar. Biol. 30: 105-117.

37. Silvi S, Barghini P, Aquilanti A, Juarez-Jimenez B, Fenice M. 2013. Physiologic and metabolic characterization of a new marine isolate (BM39) of Pantoea sp. producing high levels of exopolysaccharide. Microb. Cell Fact. 12: 10.

38. Urano N, Yamazaki M, Ueno R. 2001. Distribution of halotolerant and/or fermentative yeasts in aquatic environments. J. Tokyo Univ. Fish 87: 7.

39. Wang L, Chi Z, Wang X, Ju L, Chi Z, Guo N. 2008. Isolation and characterization of Candida membranifaciens subsp. flavinogenie W14-3, a novel riboflavin-producing marine yeast. Microbiol. Res. 163: 255-266.

40. Wenger JW, Schwartz K, Sherlock G. 2010. Bulk segregant analysis by high-throughput sequencing reveals a novel xylose utilization gene from Saccharomyces cerevisiae. PLoS
Genet. 6: e1000942.

41. White T, Bruns T, Lee S, Taylor J. 1990. Amplification and direct sequencing of fungal ribosomal RNA genes for phylogenetics, pp. 315-322. In Innis M, Gelfand D, Shinsky J, White T (eds.). PCR Protocols: A Guide to Methods and Applications. Academic Press, New York.

42. White WL, Coveny AH, Robertson J, Clements KD. 2010. Utilisation of mannitol by temperate marine herbivorous fishes. J. Exp. Mar. Biol. Ecol. 391: 50-56.

43. Wickerham LJ. 1951. Taxonomy of yeasts. US Dept. Agric. Tech. Bull. 1029: 1-56.

44. Wimalasena TT, Greetham D, Marvin ME, Liti G, Chandelia Y, Hart A, et al. 2014. Phenotypic characterisation of Saccharomyces spp. yeast for tolerance to stresses encountered during fermentation of lignocellulosic residues to produce bioethanol. Microb. Cell Fact. 13: 47.

45. Zaki AM, Wimalasena TT, Greetham D. 2014. Phenotypic characterisation of Saccharomyces spp. for tolerance to 1butanol. J. Ind. Microbiol. Biotechnol. 41: 1627-1636.

46. Zaky AS, Du C. 2014. The isolation of novel marine yeasts; a new procedure. 31(Suppl. 132). New Biotechnol. DOI: 10.1016/ j.nbt.2014.05.1939.

47. Zaky AS, Tucker GA, Daw ZY, Du C. 2014. Marine yeast isolation and industrial application. FEMS Yeast Res. 14: 813-825. 